Article

\title{
Population Dynamics of Lepidoptera Pests in Eucalyptus urophylla Plantations in the Brazilian Amazonia
}

\author{
José Cola Zanuncio ${ }^{1, *}$, Pedro Guilherme Lemes ${ }^{1}$, Germi Porto Santos ${ }^{2}$, \\ Marcus Alvarenga Soares ${ }^{3}$, Carlos Frederico Wilcken ${ }^{4}$ and José Eduardo Serrão ${ }^{5}$
}

1 Departamento de Entomologia, Universidade Federal de Viçosa, Av. P.H. Rolfs, s/n, Centro, Viçosa, Minas Gerais 36570-900, Brazil; E-Mail: pedroglemes@hotmail.com

2 Empresa de Pesquisa Agropecuária de Minas Gerais, Centro Tecnológico da Zona da Mata. Vila Gianetti, 46, Centro, Viçosa, Minas Gerais 36570-000, Brazil; E-Mail: germiporto@gmail.com

3 Departamento de Agronomia, Universidade Federal dos Vales do Jequitinhonha e Mucuri, Diamantina, Minas Gerais 39100-000, Brazil; E-Mail: marcusasoares@yahoo.com.br

4 Departamento de Produção Vegetal, Universidade Estadual Paulista "Júlio de Mesquita Filho", Botucatu, São Paulo 18603-970, Brazil; E-Mail: cwilcken@uol.com.br

5 Departamento de Biologia Geral, Universidade Federal de Viçosa, Av. P.H. Rolfs, s/n, Centro, Viçosa, Minas Gerais 36570-900, Brazil; E-Mail: jeserrao@ufv.br

* Author to whom correspondence should be addressed; E-Mail: zanuncio@ufv.br; Tel.: +55-31-38992534; Fax: +55-31-38992924.

Received: 15 October 2013; in revised form: 6 December 2013 / Accepted: 11 December 2013 / Published: 10 January 2014

\begin{abstract}
Forestry companies study the population dynamics of insect pests in Integrated Pest Management for cost effectiveness. The objective of this study was to obtain qualitative and quantitative information on population fluctuation of the Lepidopteran defoliators of Eucalyptus urophylla plants in the Brazilian Amazon rainforest. In all, 402 species were collected, of which 10 were primary pests, nine were secondary pests, and the remaining bore no definite relevance to eucalyptus. Primary pests formed a low percentage of the total species, although they recorded a high percentage of the total number of individuals. The abundance of secondary pests, except in Caracuru, was less than 150 specimens annually. Primary pests showed higher population peaks during periods of low precipitation. The small number of species and the high abundance of primary and secondary pests could be due to the availability of food, or a deficiency in natural biological control. This suggests the possibilities of population outbreaks in the eucalyptus plantations. The period of highest occurrence for insect species in these crops
\end{abstract}


must be identified so that suitable strategies can be developed for Integrated Pest Management.

Keywords: eucalyptus; light trap; monitoring; moths; integrated pest management

\section{Introduction}

Eucalyptus accounts for about $62 \%$ of the 5.4 million hectares of Brazilian forest plantations, mainly Eucalyptus grandis, E. urophylla, and E. saligna [1]. These species are grown for essential oils, charcoal, cellulose, and wood production [2,3], which reduce the pressure on native Brazilian forests [4]. Eucalyptus hybrids are important to forestry in the tropical regions, but seem to be more susceptible to pests than the pure species [5].

The increase in food supply for phytophagous insects, the low diversity of natural enemies, and the expansion of eucalyptus plantations are factors that contribute to the adaptation of new pests in these systems [6-8]. Lepidopteran defoliators are among those causing the most severe and most frequent damage in these cultures $[6,9]$.

Lepidoptera in eucalyptus plantations are distinguishable into three types: (I) primary pests (which can reach population outbreak levels), (II) secondary pests (which feed on eucalyptus but without outbreaks), and (III) the species with undefined importance, that may or may not feed on eucalyptus [7,9-11].

Monitoring Lepidoptera helps to assess the occurrence of pests and species with the potential for population outbreaks [11]. Forestry companies study insect population dynamics in Integrated Pest Management programs to cut costs of insecticides, equipment and labor in the eucalyptus plantations [12].

The biodiversity of the Amazon rainforest is hardly known. More than $70 \%$ of the species supported there have not been described, and the low number of surveys conducted shows that this paucity of knowledge looks set to continue [13]. Capturing insects with light traps, chiefly the defoliator lepidopterans, which are more active at night, is a strategy employed in biodiversity studies [14-16].

The objective of this study was to obtain qualitative and quantitative information regarding the population fluctuation of defoliator lepidopterans in Eucalyptus urophylla, in the Pará and Amapá States of the Brazilian rainforest over a five-year period.

\section{Experimental Section}

\subsection{Study Sites}

Surveys were conducted in four plantation stands composed of Eucalyptus urophylla S.T. Blake from six months of age to two years, approximately $50 \mathrm{~km}$ apart from each other, in Ponte Maria, Pacanari and Caracuru, Almeirim municipality, Pará State and Felipe, Laranjal do Jari, Amapá State, between September 1992 and August 1997 (Table 1). 
Table 1. Sampling sites in Caracuru, Pacanari and Ponte Maria, Pará State and Felipe, Amapá State, Brazil.

\begin{tabular}{ccccc}
\hline Characteristics & Caracuru & Pacanari & Ponte Maria & Felipe \\
\hline Latitude & $00^{\circ} 32^{\prime} \mathrm{S}$ & $00^{\circ} 36^{\prime} \mathrm{S}$ & $00^{\circ} 47^{\prime} \mathrm{S}$ & $00^{\circ} 54^{\prime} \mathrm{S}$ \\
Longitude & $52^{\circ} 51^{\prime} \mathrm{W}$ & $52^{\circ} 36^{\prime} \mathrm{W}$ & $52^{\circ} 47^{\prime} \mathrm{W}$ & $52^{\circ} 21^{\prime} \mathrm{W}$ \\
Altitude & $110 \mathrm{~m}$ & $126 \mathrm{~m}$ & $88 \mathrm{~m}$ & $164 \mathrm{~m}$ \\
Planting date of Eucalyptus & March 1990 & March 1992 & March 1991 & March 1990 \\
Annual rainfall & $1988.0 \mathrm{~mm}$ & $2066.5 \mathrm{~mm}$ & $2276.0 \mathrm{~mm}$ & $2276.0 \mathrm{~mm}$ \\
Annual average temperature & $28.0^{\circ} \mathrm{C}$ & $27.5^{\circ} \mathrm{C}$ & $27.3^{\circ} \mathrm{C}$ & $27.5^{\circ} \mathrm{C}$ \\
Annual average relative humidity & $86.6 \%$ & - & $84.0 \%$ & $84.0 \%$ \\
\hline
\end{tabular}

\subsection{Lepidoptera Sampling}

Each area was monitored every two weeks for sixty continuous months (120 trap-nights per site) using one light trap (Model Intral AL 012) equipped with fluorescent black-light bulb F15 T12 LN (wavelength from 290 to $450 \mathrm{~mm}$ ), powered by a 12-V and 55 A battery. The light trap was set at the midpoint of each eucalyptus stand [15], $2 \mathrm{~m}$ from the ground, and operated from 6 p.m. to 6 a.m., accumulating 1560 trap-hours at each site. A plastic bag, containing paper strips, and a bottle with ethyl acetate was coupled to the funnel trap to speed-up death and reduce damage to the collected insects.

The insects collected were sorted, packed, and sent to the Laboratory of Biological Control of Insects of the Department of Entomology at the Universidade Federal de Viçosa (UFV) in Viçosa, Minas Gerais State, Brazil. Insects were identified by the taxonomists from the Center for Phytophagous Insect Identification of the Universidade Federal do Paraná and other centers, and by comparing them with the specimens from the Regional Museum of Entomology/UFV (UFVB). They were deposited in the collections of the Regional Museum of Entomology/UFV and the collection of Jari Celulose, Papel e Embalagens S.A., in Monte Dourado, State of Pará, Brazil.

The lepidopteran specimens collected were divided into groups I, II, and III, representing the primary pests, secondary pests, and species without defined importance to eucalyptus, respectively [11].

\subsection{Data Analysis}

Climatic data were collected from the weather stations of Monte Dourado (Ponte Maria and Felipe), São Miguel (Caracuru and Pacanari). Rainfall refers to the accumulated total for the month, while temperature indicates the monthly average of the collection period. Abundances were transformed to a logarithmic scale to assist visualization and interpretation of the results where necessary.

\section{Results and Discussion}

A total of 402 species of Lepidoptera were collected; 10 primary pest species, 9 secondary pests, and the rest without defined importance to eucalyptus. In all 31,865 individuals were collected over five years (total effort $=6240$ trap-hours). Among these, $43.53 \%$ comprised primary pests, $4.99 \%$ secondary pests, and $51.48 \%$ species without defined importance. 
The number of primary pest species was similar in all the locations; however, Ponte Maria had eight secondary pest species, one less than the other locations. These species belonged to the families Arctiidae, Geometridae, Lymantriidae, and Notodontidae, the first with the highest number of species (Table 2). Secondary pests were from six families, with Saturniidae presenting the largest number of species (Table 3).

Primary pests showed a lower percentage of species, 3.08\%, 2.88\%, 3.04\%, and 3.28\%, and a substantial percentage of individuals, $14.54 \%, 44.68 \%, 68.46 \%$, and $20.65 \%$, in Ponte Maria, Pacanari, Caracuru and Felipe, respectively. In Pacanari and Caracuru, $85.40 \%$ of the total individuals were the primary pests, while in the other two sites with plantations near native forests, this value was only $7.28 \%$ and $7.32 \%$, respectively (Figure 1A). The occurrence of secondary pests was similar in the four sites (Figure 1B) and the species without defined importance had a higher number of individuals in Ponte Maria (Figure 1C). The most collected species of group I in Ponte Maria were Stenalcidia grosica, mainly in the fourth year; Thyrinteina arnobia in the fifth, and Oxydia vesulia in the third, corresponding to $31.23 \%, 30.83 \%$, and $11.82 \%$ respectively, of the total individuals of primary pests. In Pacanari, T. arnobia showed peaks in the second, fourth, and fifth years, while $S$. grosica peaked in the fourth, corresponding to $39.60 \%$ and $37.12 \%$, respectively, of the total collected. These two species accounted for $84.54 \%$ of the total specimens collected in Caracuru, with outbreaks of T. arnobia $(64.67 \%)$ in the fourth and fifth years, and S. grosica $(19.87 \%)$ in the fourth. The most collected species in Felipe were $S$. grosica (29.91\%) with a higher incidence in the fourth year, O. vesulia $(23.46 \%)$ in the second, and T. arnobia $(17.03 \%)$ in the fifth.

The number of species of group II varied between locations over the five years of the study and a sharp decline in the number of species was recorded, mostly in the last year. The abundance of secondary pests, except in Caracuru, with a greater number of individuals in the second year, was noted to be less than 150 specimens per year, with lower values in the first and fifth years at all locations (Figures 1B, 2C, 3C, 4C and 5C).

In Ponte Maria, Idalus admirabilis with $31.62 \%$, Eacles ducalis with $21.94 \%$, and Eacles imperialis magnifica with $20.79 \%$, were the most collected species of this group. In Pacanari, I. admirabilis and E. ducalis were the most frequent, with $55.42 \%$ and $20.08 \%$ of the number of individuals, respectively, while in Caracuru, I. admirabilis was the most collected secondary pest, with $65.3 \%$ of the individuals. In Felipe, the most frequent secondary pest species were I. admirabilis and E. ducalis, with $52.47 \%$ and $14.81 \%$ of the individuals, respectively.

The number of individuals of the species of group III decreased towards the end of the collecting period in the eucalyptus plantations. The occurrence of these insects increased between the first and second year in Felipe (Figure 5D) and with a higher number in Ponte Maria (Figure 2D). Moreover, this number decreased, in Pacanari, from the first to the third year, increased in the fourth, and decreased in the fifth with the lowest number of individuals in all sites (Figure 3D). 
Table 2. Number of individuals of Lepidoptera primary pest species collected in Eucalyptus urophylla plantations in Monte Dourado, Pará and Amapá States, Brazil. T is Sub-total; GT is Grand Total.

\begin{tabular}{|c|c|c|c|c|c|c|c|c|c|c|c|c|c|c|c|c|c|c|c|c|c|c|c|c|c|}
\hline Site & & & Pon & te Ma & & & & & & canari & & & & & & racurt & & & & & & elipe & & & GT \\
\hline $\begin{array}{c}\text { Family/Year } \\
\text { Arctiidae }\end{array}$ & I & II & III & IV & $\mathrm{V}$ & $\mathrm{T}$ & I & II & III & IV & $\mathrm{V}$ & $\mathrm{T}$ & I & II & III & IV & $\mathrm{V}$ & $\mathrm{T}$ & I & II & III & IV & $\mathrm{V}$ & $\mathrm{T}$ & \\
\hline Eupseudosoma aberrans & 24 & 17 & 16 & 12 & 9 & 78 & 56 & 64 & 40 & 41 & 14 & 215 & 147 & 44 & 43 & 32 & 18 & 284 & 28 & 27 & 9 & 11 & 0 & 75 & 652 \\
\hline $\begin{array}{c}\text { Eupseudosoma involuta } \\
\text { Geometridae }\end{array}$ & 16 & 15 & 18 & 4 & 1 & 54 & 90 & 27 & 14 & 16 & 1 & 148 & 99 & 164 & 7 & 15 & 11 & 296 & 22 & 11 & 6 & 1 & 2 & 42 & 540 \\
\hline Glena sp. & 0 & 8 & 7 & 2 & 6 & 23 & 0 & 39 & 8 & 63 & 17 & 127 & 4 & 17 & 15 & 54 & 1 & 91 & 5 & 11 & 2 & 6 & 2 & 26 & 267 \\
\hline Oxydia vesulia & 2 & 27 & 81 & 6 & 4 & 120 & 26 & 8 & 24 & 11 & 1 & 70 & 27 & 12 & 5 & 18 & 1 & 63 & 32 & 87 & 57 & 61 & 0 & 237 & 490 \\
\hline Stenalcidia grosica & 15 & 39 & 65 & 137 & 61 & 317 & 15 & 82 & 46 & 1091 & 50 & 1284 & 75 & 50 & 27 & 1385 & 129 & 1666 & 54 & 14 & 33 & 181 & 20 & 302 & 3,569 \\
\hline $\begin{array}{c}\text { Thyrinteina arnobia } \\
\text { Lymantriidae }\end{array}$ & 19 & 12 & 5 & 13 & 264 & 313 & 11 & 247 & 44 & 266 & 802 & 1370 & 27 & 17 & 15 & 411 & 4950 & 5420 & 3 & 1 & 4 & 36 & 128 & 172 & 7,275 \\
\hline $\begin{array}{l}\text { Sarsina violascens } \\
\text { Notodontidae }\end{array}$ & 8 & 14 & 1 & 18 & 9 & 50 & 6 & 3 & 4 & 18 & 12 & 43 & 23 & 2 & 17 & 189 & 18 & 249 & 37 & 21 & 4 & 26 & 10 & 98 & 440 \\
\hline Misogada blerula & 11 & 8 & 3 & 3 & 2 & 27 & 20 & 52 & 1 & 15 & 3 & 91 & 76 & 17 & 1 & 46 & 0 & 140 & 3 & 13 & 0 & 7 & 0 & 23 & 281 \\
\hline Nystalea nyseus & 10 & 3 & 2 & 2 & 10 & 27 & 52 & 1 & 1 & 3 & 52 & 109 & 3 & 148 & 7 & 3 & 3 & 164 & 11 & 3 & 4 & 5 & 11 & 34 & 334 \\
\hline Psorocampa denticulata & 1 & 1 & 1 & 3 & 0 & 6 & 0 & 1 & 1 & 0 & 0 & 2 & 0 & 8 & 0 & 0 & 0 & 8 & 0 & 0 & 0 & 1 & 0 & 1 & 17 \\
\hline Total & & & & & & 1015 & & & & & & 202 & & & & & & 312 & & & & & & 58 & 13,865 \\
\hline
\end{tabular}


Table 3. Number of individuals of Lepidoptera secondary pest species collected in Eucalyptus urophylla plantations in Monte Dourado, Pará and Amapá States, Brazil. T is Sub-total; GT is Grand Total.

\begin{tabular}{|c|c|c|c|c|c|c|c|c|c|c|c|c|c|c|c|c|c|c|c|c|c|c|c|c|c|}
\hline \multirow{2}{*}{$\begin{array}{c}\text { Site } \\
\text { Family/Year } \\
\text { Amatidae }\end{array}$} & \multicolumn{6}{|c|}{ Ponte Maria } & \multicolumn{6}{|c|}{ Pacanari } & \multicolumn{6}{|c|}{ Caracuru } & \multicolumn{6}{|c|}{ Felipe } & \multirow[t]{2}{*}{ GT } \\
\hline & I & II & III & IV & $\mathrm{V}$ & $\mathrm{T}$ & I & II & III & IV & $\mathrm{V}$ & $\mathrm{T}$ & I & II & III & IV & V & $\mathrm{T}$ & I & II & III & IV & V & $\mathrm{T}$ & \\
\hline $\begin{array}{c}\text { Cosmosoma auge } \\
\text { Arctiidae }\end{array}$ & 1 & 5 & 3 & 4 & 1 & 14 & 2 & 1 & 0 & 2 & 0 & 5 & 3 & 0 & 3 & 0 & 0 & 6 & 0 & 0 & 3 & 1 & 0 & 4 & 29 \\
\hline $\begin{array}{c}\text { Idalus admirabilis } \\
\text { Eucleidae }\end{array}$ & 9 & 34 & 30 & 17 & 21 & 111 & 9 & 41 & 26 & 53 & 9 & 138 & 45 & 299 & 38 & 48 & 5 & 435 & 40 & 67 & 45 & 16 & 2 & 170 & 85 \\
\hline $\begin{array}{c}\text { Phobethon hypparchia } \\
\text { Megalopygidae }\end{array}$ & 1 & 5 & 2 & 3 & 2 & 13 & 0 & 1 & 6 & 4 & 2 & 13 & 0 & 15 & 3 & 11 & 0 & 29 & 10 & 2 & 0 & 1 & 1 & 14 & 65 \\
\hline $\begin{array}{c}\text { Megalopyge albicollis } \\
\text { Mimallonidae }\end{array}$ & 1 & 6 & 24 & 3 & 3 & 37 & 2 & 4 & 4 & 4 & 1 & 15 & 2 & 52 & 1 & 0 & 0 & 55 & 4 & 15 & 9 & 0 & 0 & 28 & 135 \\
\hline $\begin{array}{l}\text { Mimallo amilia } \\
\text { Saturniidae }\end{array}$ & 2 & 7 & 8 & 1 & 1 & 19 & 6 & 1 & 6 & 0 & 0 & 13 & 4 & 38 & 6 & 2 & 0 & 50 & 4 & 15 & 0 & 0 & 0 & 19 & 101 \\
\hline Eacles ducalis & 5 & 14 & 32 & 16 & 10 & 77 & 10 & 13 & 7 & 17 & 3 & 50 & 11 & 18 & 1 & 0 & 6 & 36 & 4 & 15 & 11 & 9 & 9 & 48 & 211 \\
\hline Automeris illustris & 0 & 0 & 0 & 0 & 0 & 0 & 0 & 1 & 2 & 1 & 0 & 4 & 1 & 3 & 0 & 2 & 0 & 6 & 0 & 1 & 4 & 5 & 1 & 11 & 21 \\
\hline Eacles imperialis magnifica & 24 & 37 & 3 & 9 & 0 & 73 & 7 & 3 & 0 & 0 & 0 & 10 & 5 & 0 & 1 & 0 & 0 & 6 & 13 & 7 & 1 & 0 & 0 & 21 & 110 \\
\hline Dirphia sp. & 4 & 3 & 0 & 0 & 0 & 7 & 0 & 1 & 0 & 0 & 0 & 1 & 8 & 4 & 6 & 23 & 2 & 43 & 5 & 1 & 1 & 2 & 0 & 9 & 60 \\
\hline Total & & & & & & 157 & & & & & & 249 & & & & & & 91 & & & & & & 324 & 1590 \\
\hline
\end{tabular}


Figure 1. Number of individuals of Lepidoptera primary pests (A), secondary pests (B), and species with no defined importance to eucalypts (C) collected in Eucalyptus urophylla plantations in Ponte Maria, Pacanari, Caracuru, Pará State, and Felipe, Amapá State, Brazil.
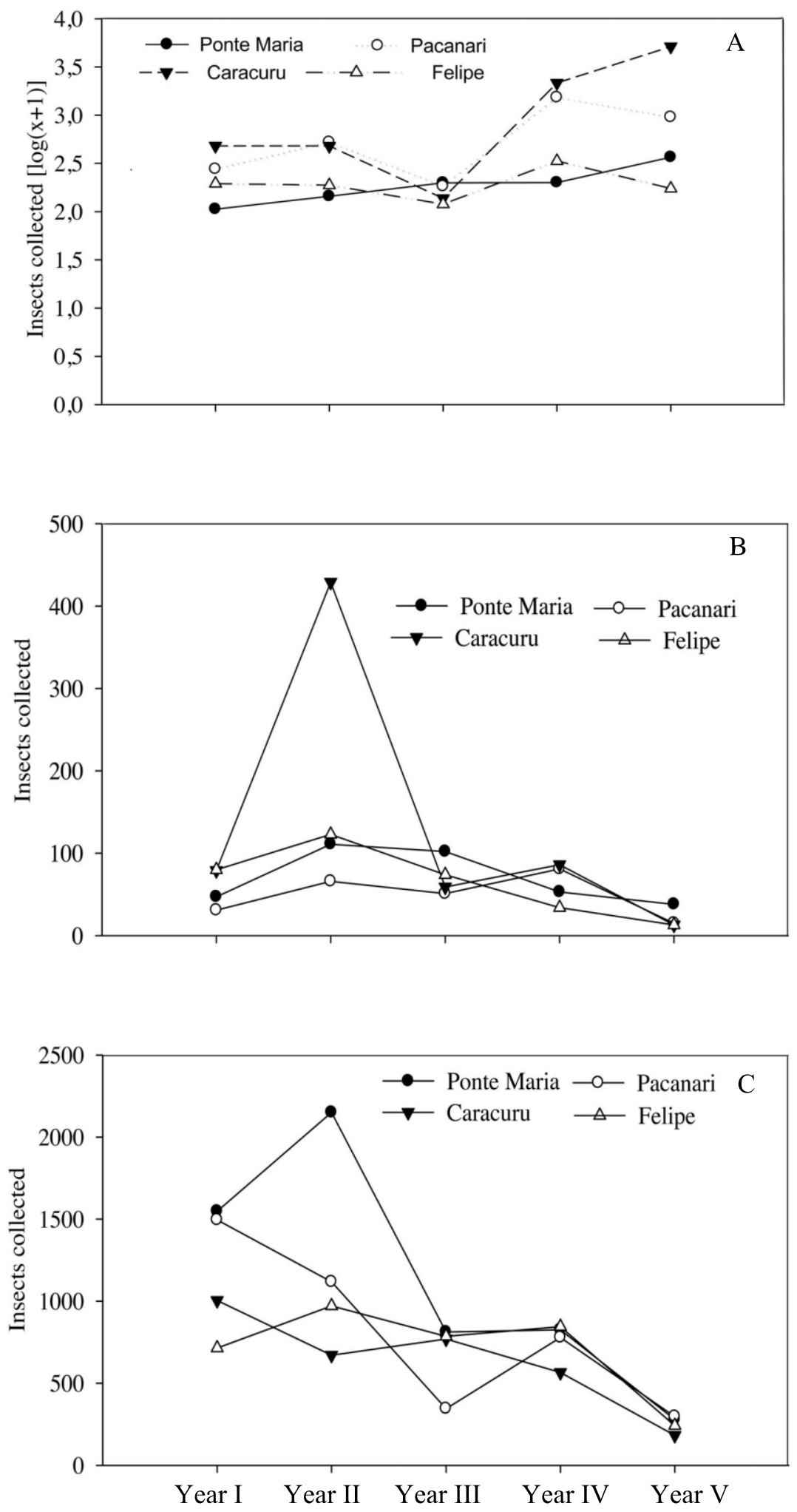

September 1992 to August 1997 
The occurrence of the lepidopteran defoliators in the different locations studied showed higher population peaks of primary pests during the low rainfall periods (Figures 2B, 3B, 4B, and 5B).

No individual of primary pest was collected in Ponte Maria in January of the first, second, and fourth years, and in May of the fifth. The highest peaks of species of this group occurred in July, April, July, June, and November, respectively, from the first to the fifth year. Species belonging to group II did not occur between October and December of the first year; in October of the second; November of the third, January of the fourth, and February and June of the fifth. Species without importance to the eucalypts showed population peaks with high fluctuations, especially in August of the first year and in March of the second (Figure 2)

Primary pests were not collected in Pacanari between September and January of the first year; January and December of the fourth; and January and February of the last year. The highest population peaks of this group were recorded in April, October, October, July, and September, from the first to fifth year, respectively. Secondary pests were not collected between September and December of the first year; March and November of the second; May, September, and October of the third; January and November of the fourth; and from April to May and November to December in the last year of the evaluation. This group showed the highest population peak in June of the fourth year. Species without defined importance showed the highest population peak in February of the first year (Figure 3).

In Caracuru, primary pests were not found in October and November of the second year, in December of the fourth, and January to February and May of the last year. The secondary pests did not occur in November of the first year; in November and December of the third; in November of the fourth; and in March, May, July, and September to November of the fifth, with a population peak in April of the second year. The population peak of the species of the third group showed a higher variation from the second half of the collection period (Figure 4).

The collections in Felipe showed that primary pests were not observed in October of the second year, and January and November of the fourth. The highest population outbreaks of this group were recorded in June, May, September, July, and September, from the first to the fifth year, respectively. The secondary pests were not collected between September and November of the first year; in December of the third; in January and February and from October to November of the fourth, and in January, March, May, June, August, and November of the last year. The highest population peak of this group was recorded in April of the second year while the lowest was noted in the fifth year. Peak population of the species without defined importance for eucalypts showed a low variation over the years (Figure 5).

Species of primary and secondary pests included $48.52 \%$ of the total number of individuals, which was only $4.72 \%$ of the total species, showing their adaptation to the eucalyptus plantations $[7,9,11,12,17]$. Species of the native vegetation may migrate to the eucalypts due to the abundant food supply where they can become pests in several regions of Brazil [8,12]. The low number of species and the high number of the individuals of these two groups could probably be due to availability of food or to poor natural biological control to reduce their populations [10]. The high number of individuals of these groups suggests the possibility of population outbreaks in eucalyptus plantations. However, food supply is not the only factor to favor outbreaks of Lepidoptera; some environmental conditions unfavorable to plants also play a role [18]. 
Figure 2 Rainfall $(\mathrm{mm})$ and temperature $\left({ }^{\circ} \mathrm{C}\right)(\mathbf{A})$, population dynamics of primary pests (B), secondary pests (C), and species with no defined importance to eucalypts (D) in Ponte Maria, Pará State, Brazil.
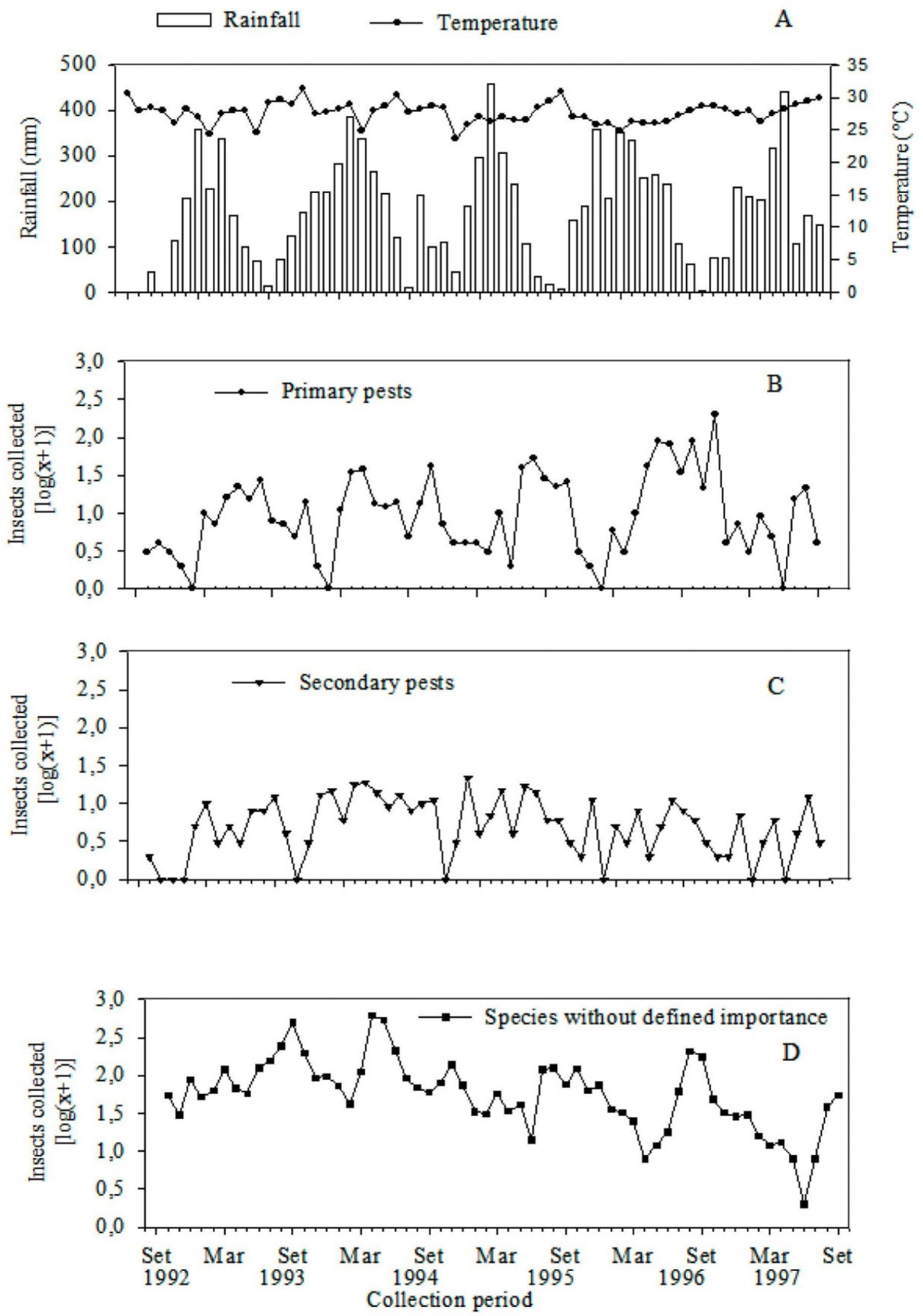
Figure 3 Rainfall $(\mathrm{mm})$ and temperature $\left({ }^{\circ} \mathrm{C}\right)(\mathbf{A})$, population dynamics of primary pests (B), secondary pests $(\mathbf{C})$, and species with no defined importance to eucalypts (D) in Pacanari, Pará State, Brazil.
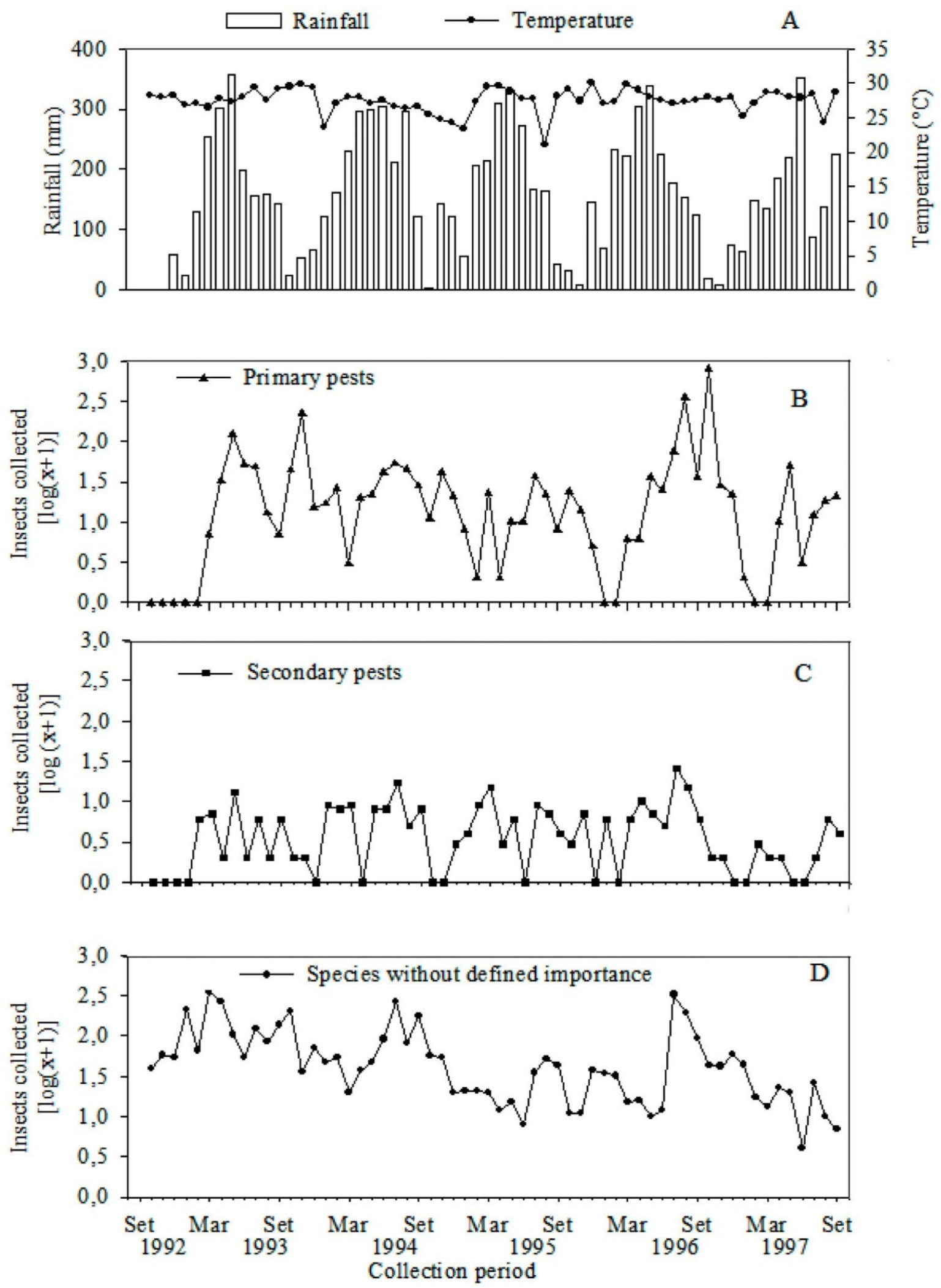
Figure 4. Rainfall $(\mathrm{mm})$ and temperature $\left({ }^{\circ} \mathrm{C}\right)(\mathbf{A})$, population dynamics of primary pests (B), secondary pests $(\mathbf{C})$, and species with no defined importance to eucalypts (D) in Caracuru, Pará State, Brazil.
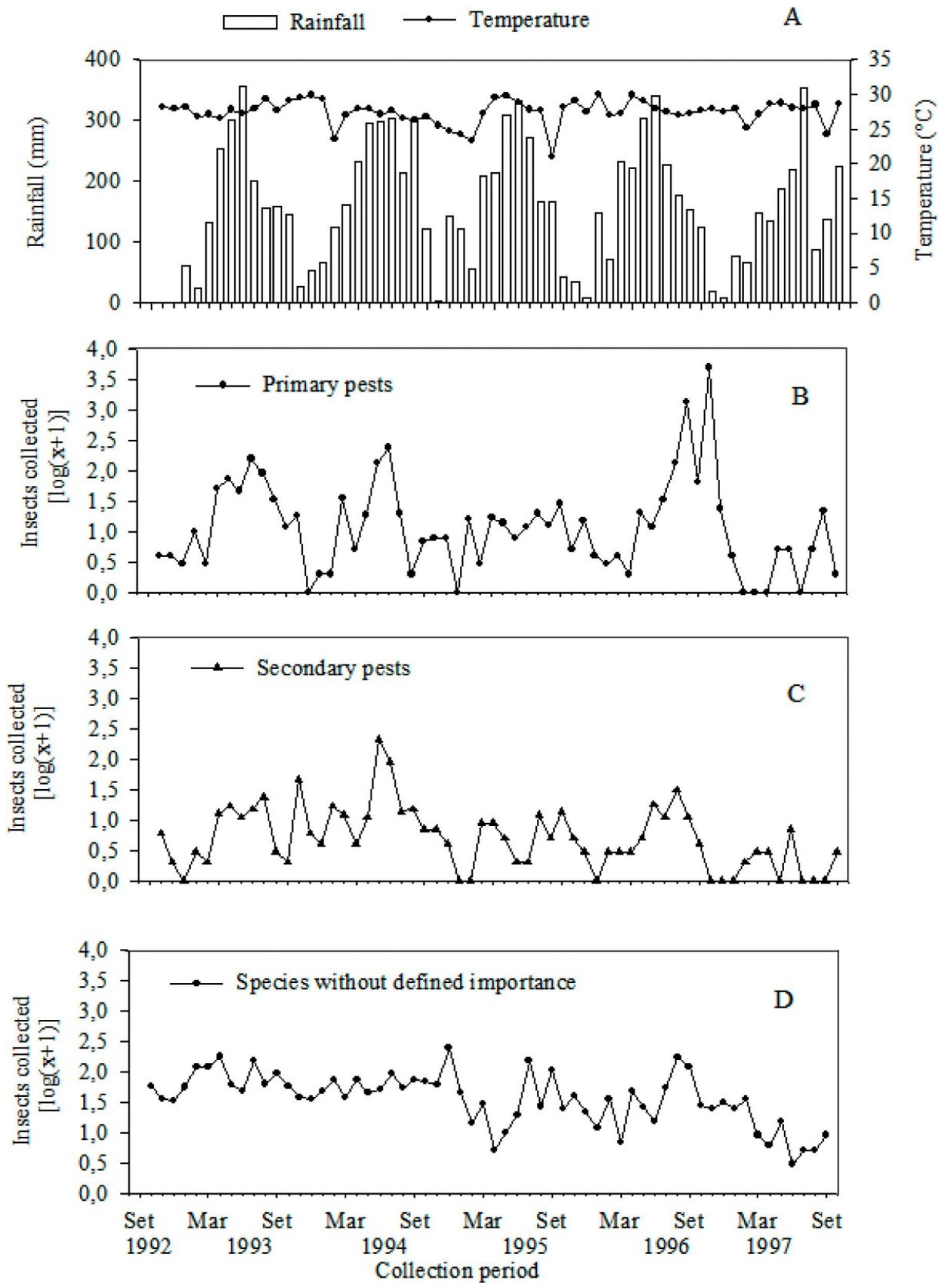
Figure 5. Rainfall $(\mathrm{mm})$, temperature $\left({ }^{\circ} \mathrm{C}\right)(\mathbf{A})$, population dynamics of primary pests $(\mathbf{B})$, secondary pests $(\mathbf{C})$, and species with no defined importance to eucalypts (D) in Felipe, Amapá State, Brazil.
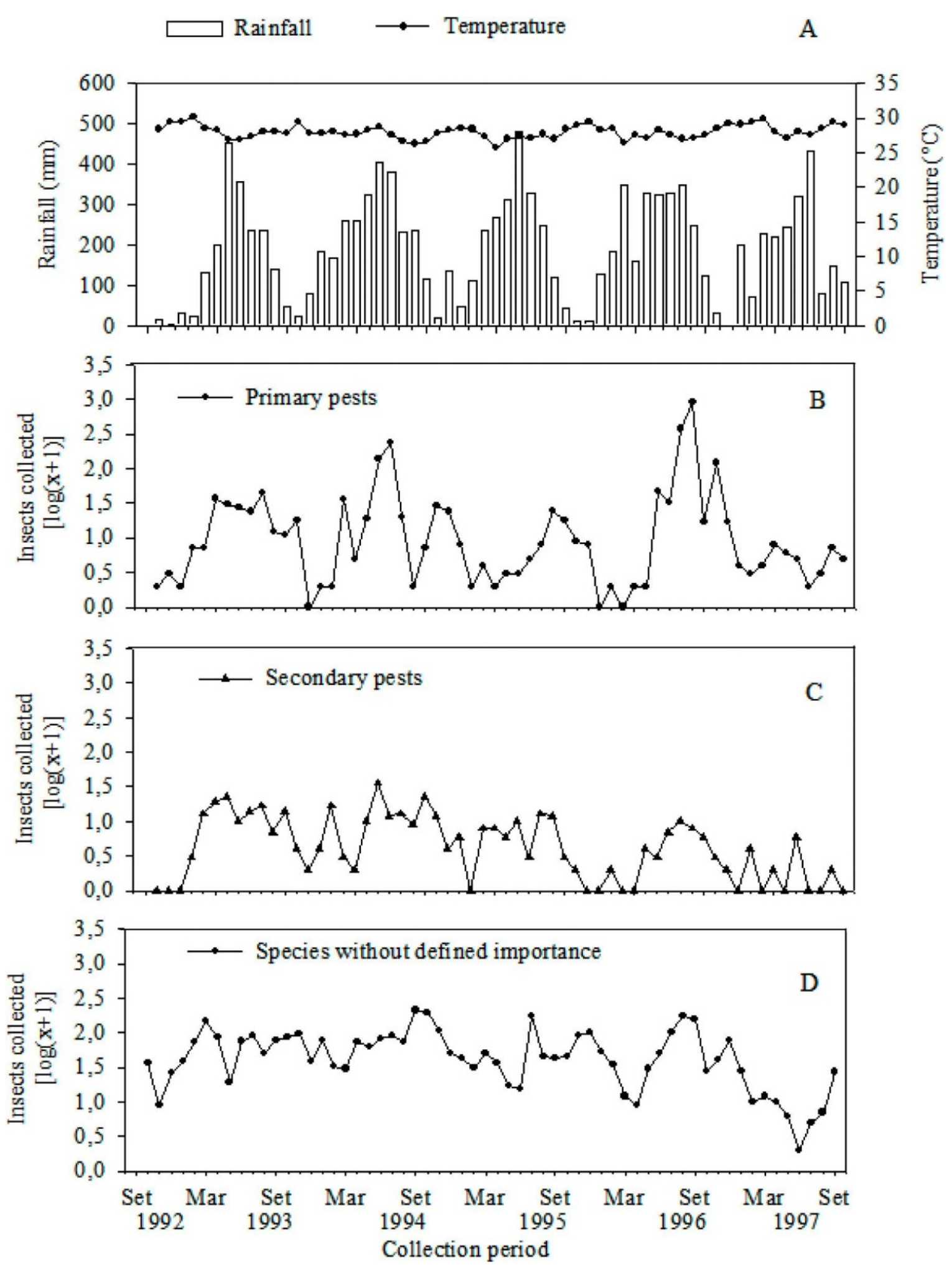
Stenalcidia grosica and T. arnobia were found to be the most abundant primary pests. They were present in all the locations studied during the five-year period. The first one, abundant and frequent in other regions of Brazil [7,9,10], showed a similar trend, as the second most collected, and exceeding T. arnobia in some sites, suggesting that it deserves attention in monitoring. The same should be applied to T. arnobia, with a history of outbreaks in eucalyptus and one of the most important defoliators of this plant [9,19]. Psorocampa denticulata showed low abundance of occurrence. It did not occur in most years, and showed reduced frequency in the total number of individuals; however, it is one of the most frequent in other Brazilian regions $[6,11,12,16]$ during periods of rainfall [11]. This species exhibits diapause in the pre-pupal stage and requires periods of low and high humidity to complete the cycle. The high rainfall period in the region may not be favorable for this insect.

The population peaks of group I pests were similar to those of the other areas of Brazil, usually during the drier months and with warmer temperatures when the plants may exhibit stress mainly due to water deficit $[6,7,11,12,20]$. Stress in the eucalyptus trees may favor the establishment of insect pests, due to lowered plant defenses [7,21].

The small number of individuals occurring in the plantations of Ponte Maria and Felipe may be related to the proximity of remnant Amazonian native forest, which favors migration of natural enemies to eucalyptus plantations to regulate the populations of these insects. This was reported for the Lepidoptera collected in Eucalyptus cloeziana plantations in Minas Gerais State, Brazil, near forest reserves [22].

The abundance of primary and secondary pests in Felipe and Ponte Maria showed the importance of the proximity of natural forest areas to the plantations, although with smaller areas than those of Pacanari and Caracuru, which were distant from the plantations. Fragments and corridors of native forest in eucalyptus monocultures can increase the diversity of natural enemies and reduce difficulties with the insect pests $[10,23,24]$. Furthermore, the distance between the plantations and natural vegetation may be more important than the reserve area, possibly because of the source of natural enemies.

Secondary pests include those registered in other regions of Brazil; however, I. admirabilis deserves more attention as the number of individuals of this species ranked between third and fifth place of all primary and secondary pests. These results are similar to those reported for eucalyptus plantations in Goiás and Minas Gerais States, Brazil [9,12,17].

The low abundance within species that show no defined importance to eucalypts, as in other regions of Brazil, suggests that they do not feed on the eucalyptus trees, but on plants of the understory vegetation or those near plantations [10,12].

The low variation in the number of species of groups I and II reinforces the hypothesis that some species are adapted to thrive on eucalyptus, unlike the large number of those of group III. This can be explained by the herbivore host plants present and cultural practices, such as weeding, which may restrict the food supply for the species of this group. Eucalyptus plantations normally have fewer interventions from the third or fourth years, which may favor the persistence and proliferation of natural enemies to control the insect defoliators [25]. 


\section{Conclusions}

It is important to identify the period of the highest occurrence of insects in the eucalypt plantations, especially those of groups I and II. This information will enable the development of suitable integrated pest management strategies that can reduce the costs and facilitate the monitoring and control programs of insect pests. There is a relationship between the population of Lepidoptera pests and climatic variables. The more abundant primary pests were T. arnobia, S. grosica, and O. vesulia that had population peaks during periods of low rainfall. As the abundance of these pests has not changed during the period of five years it is necessary to continue monitoring these areas throughout the planting cycle. Additionally, it provides information on the degree of adaptation of primary and secondary pest species and the potential of other species to become pests.

\section{Acknowledgments}

To "Conselho Nacional de Desenvolvimento Científico e Tecnológico (CNPq)", "Coordenação de Aperfeiçoamento de Pessoal de Nível Superior (CAPES)" and "Fundação de Amparo à Pesquisa do Estado de Minas Gerais (FAPEMIG)" for financial support. Global Edico Services revised and edited this manuscript.

\section{Conflicts of Interest}

The authors declare no conflict of interest.

\section{References}

1. Luiz de Queiroz, D.; Zanol, K.M.R.; Oliveira, E.B.; Anjos, N.; Majer, J. Feeding and oviposition preferences of Ctenarytaina spatulata Taylor (Hemiptera, Psyllidae) for Eucalyptus spp. and other Myrtaceae in Brazil. Revista Bras. Entomol. 2010, 54,149-153.

2. Elaissi, A.; Salah, K.H.; Mabrouk, S.; Larbi, K.M.; Chemli, R.; Harzallah-Skhiri, F. Antibacterial activity and chemical composition of 20 Eucalyptus species' essential oils. Food Chem. 2011, 129, 1427-1434.

3. Brissola, S.H.; Demarco, D. Stem anatomical analysis of Eucalyptus grandis, E. urophylla and E. grandis $\times$ E. urophylla: wood development and its industrial importance. Scientia Forestalis 2011, 39, 317-330.

4. Zanuncio, A.J.V.; Pastori, P.L.; Kirkendall, L.R.; Lino-Neto, J.; Serrão, J.E.; Zanuncio, J.C. Megaplatypus mutatus (Chapuis) (Coleoptera: Curculionidae: Platypodinae) attacking hybrid Eucalyptus clones in southern Espírito Santo, Brazil. Coleopt. Bull. 2010, 64, 81-83.

5. Potts, B.M.; Dungey, H.S. Interspecific hybridization of Eucalyptus: Key issues for breeders and geneticists. New For. 2004, 27, 115-138.

6. Zanuncio, J.C.; Zanuncio, T.V.; Freitas, F.A.; Pratissoli, D. Population density of Lepidoptera in a plantation of Eucalyptus urophylla in the State of Minas Gerais, Brazil. Anim. Biol. 2003, 53, $17-26$. 
7. Freitas, F.A.; Zanuncio, T.V.; Zanuncio, J.C.; Conceição, P.M.; Fialho, M.C.Q.; Bernardino, A.S. Effect of plant age, temperature and rainfall on Lepidoptera insect pests collected with light traps in a Eucalyptus grandis plantation in Brazil. Ann. For. Sci. 2005, 62, 85-90.

8. Pereira, A.I.A.; Curvêlo, C.R.S.; Guerra, A.M.N.M.; Andrade, G.S.; Zanuncio, J.C. Eucalyptus cloeziana as a new host to Hylesia paulex (Lepidoptera: Saturniidae) in Southeast Brazil. Revista Caatinga 2009, 22, 1-5.

9. Zanuncio, J.C.; Guedes, R.N.C.; Zanuncio, T.V.; Fabres, A.S. Species richness and abundance of defoliating Lepidoptera associated with Eucalyptus grandis in Brazil and their response to plant age. Austral Ecol. 2001, 26, 582-589.

10. Zanuncio, T.V.; Zanuncio, J.C.; Miranda, M.M.M.; Medeiros, A.G.B. Effect of plantation age on diversity and population fluctuation of Lepidoptera collected in Eucalyptus plantations in Brazil. For. Ecol. Manag. 1998, 108, 91-98.

11. Zanuncio, T.V.; Zanuncio, J.C.; Freitas, F.A.; Pratissoli, D.; Sediyama, C.A.Z.; Maffia, V.P. Main lepidopteran pest species from an eucalyptus plantation in Minas Gerais, Brazil. Revista Biol. Trop. 2006, 54, 553-560.

12. Pereira, J.M.M.; Zanuncio, T.V.; Zanuncio, J.C.; Pratissoli, D. Lepidoptera pests collected in Eucalyptus urophylla plantations during five years in Três Marias, State of Minas Gerais, Brazil. Revista Biol. Trop. 2001, 49, 997-1006.

13. Salati, E.; dos Santos, Â.A.; Klabin, I. Relevant environmental issues. Estud. Av. 2006, 20, $107-127$.

14. Kitching, R.L.; Orr, A.G.; Thalib, L.; Mitchell, H.; Hopkins, M.S.; Graham, A.W. Moth assemblages as indicators of environmental quality in remnants of upland Australian rain forest. $J$. Appl. Ecol. 2000, 37, 284-297.

15. Osaki, K.; Sayama, K.; Ueda, A.; Ito, M.; Tabuchi, K.; Hironaga, T. Short-term, efficient sampling strategies for estimating forest moth diversity using light traps. Ann. Entomol. Soc. Am. 2011, 104, 739-748.

16. Hawes, J.; Motta, C.S.; Overal, W.L.; Barlow, J.; Gardner, T.A.; Peres, C.A. Diversity and composition of Amazonian moths in primary, secondary and plantation forests. J. Trop. Ecol. 2009, 25, 281-300.

17. Zanuncio, J.C.; Zanuncio, T.V.; Lopes, E.T.; Ramalho, F. Temporal variation of Lepidoptera collected in an Eucalyptus plantation in the state of Goiás, Brazil. Neth. J. Zool. 2000, 50, 435-443.

18. Wallner, W.E. Factors affecting insect population dynamics: Differences between outbreak and non-outbreak species. Ann. Rev. Entomol. 1987, 32, 317-340.

19. Oliveira, H.N.; Zanuncio, J.C.; Pedruzzi, E.P.; Espindula, M.C. Rearing of Thyrinteina arnobia (Lepidoptera: Geometridae) on guava and eucalyptus in laboratory. Braz. Arch. Biol. Technol. 2005, 48, 801-806.

20. Zanuncio, J.C.; Alves, J.B.; Santos, G.P.; Campos, W.O. Levantamento e flutuação populacional de lepidópteros associados à eucaliptocultura: VI- Região de Belo Oriente, Minas Gerais. Pesqui. Agropecu. Bras. 1993, 28, 1121-1127. 
21. Paine, T.D.; Hanlon, C.C. Integration of tactics for management of Eucalyptus herbivores: influence of moisture and nitrogen fertilization on red gum lerp psyllid colonization. Entomol. Exp. Appl. 2010, 137, 290-295.

22. Zanuncio, J.C.; Mezzomo, J.A.; Guedes, R.N.C.; Oliveira, A.C. Influence of strips of native vegetation on Lepidoptera associated with Eucalyptus cloeziana in Brazil. For. Ecol. Manag. 1998, 108, 85-90.

23. Thomas, J.A.; Bourn, N.A.D.; Clarke, R.T.; Stewart, K.E.; Simcox, D.J.; Pearman, G.S.; Curtis, R.; Goodger, B. The quality and isolation of habitat patches both determine where butterflies persist in fragmented landscapes. Proc. Biol. Sci. 2001, 268, 1791-1796.

24. Teja, T.; Roland, B. Plant-insect interactions in fragmented landscapes. Ann. Rev. Entomol. 2004, 49, 405-430.

25. Watt, A.D.; Stork, N.E.; Mcbeath, C.; Lawson, G.L. Impact of forest management on insect abundance and damage in a lowland tropical forest in southern Cameroon. J. Appl. Ecol. 1997, 34, 985-998.

(C) 2014 by the authors; licensee MDPI, Basel, Switzerland. This article is an open access article distributed under the terms and conditions of the Creative Commons Attribution license (http://creativecommons.org/licenses/by/3.0/). 